\title{
Thermal ecotypes of amphi-Atlantic algae. II. Cold-temperate species (Furcellaria lumbricalis and Polyides rotundus)
}

\author{
I. Novaczek \& A. M. Breeman \\ Department of Marine Biology, Biological Centre, University of Groningen; \\ P.O. Box 14, NL-9750 AA Haren (Gn), The Netherlands
}

\begin{abstract}
Two species of cold-temperate algae from the North Atlantic Ocean, Polyides rotundus and Furcellaria lumbricalis, were tested for growth and survival over a temperature range of $\mathbf{- 5}$ to $30^{\circ} \mathrm{C}$. In comparisons of eastern and western isolates, both $F$. lumbricalis, a North Atlantic endemic, and $P$. rotundus, a species having related populations in the North Pacific, were quite homogeneous. $F$. lumbricalis tolerated -5 to $25^{\circ} \mathrm{C}$ and grew well from 0 to $25^{\circ} \mathrm{C}$, with optimal growth at $10-15^{\circ} \mathrm{C}$. $P$. rotundus tolerated -5 to $27^{\circ} \mathrm{C}$, grew well from 5 to $25^{\circ} \mathrm{C}$, and had a broad optimal range of $10-25^{\circ} \mathrm{C}$. Both species tolerated 3 months in darkness at $0{ }^{\circ} \mathrm{C}$. In neither case could any geographic boundary be explained in terms of lethal seasonal temperatures, suggesting that these species are restricted in distribution by strict thermal and/or daylength requirements for reproduction. The hypothesis that northern species are more homogeneous than southern taxa in terms of thermal tolerance was supported. A second hypothesis, that disjunct cold-temperate species should be more variable than pan-Arctic species, was not supported.
\end{abstract}

\section{INTRODUCTION}

Algal species currently occupying both sides of the North Atlantic Ocean may have evolved in the Arctic or Atlantic; they may also have been introduced either from the North Pacific via the Arctic Ocean, or from the south Pacific via either the Caribbean or Tethys Seas (Novaczek et al., 1990). For some millions of years, thermal regimes of the eastern and western coasts of the North Atlantic have differed to a relatively large degree. As a result of the variety of origins, different degrees of genetic isolation between eastern and western populations, and the variety of thermal stresses encountered, one might expect amphi-Atlantic species to have developed varying degrees of ecotypic variation in thermal response. We have hypothesized that species of southern origin that have been in the Atlantic for more than 100 my may have evolved into relatively large numbers of thermal ecotypes or even new species in response to a long history of thermal change. In contrast, northern species that have been more recently introduced to the ocean might be more uniform, or might show ecotypic variation only in the southernmost border populations that are under the most stress from high summer temperatures (cf. Gerard \& Du Bois, 1988).

Northern species can be divided into 2 broad categories. Some of those that are also found in the North Pacific may have entered the Atlantic via the Arctic as recently as 2-3 
my BP, following the disruption of Beringia. Others having affinities to Pacific species as well as algae endemic to the North Atlantic may be descended from species that were in the Arctic Ocean when it first became isolated from the Pacific by Beringia. These ancestral algae would then have been able to enter the Atlantic after the separation of Greenland from Norway some $50 \mathrm{my}$ BP, and the subsequent cooling of the North Atlantic basin. Compared to the more recent invaders, such Arctic algae can be expected to be only distantly related to their North Pacific congeners. Owing to their long residence in the Atlantic, they may also have more ecotypic variants than recently introduced species, although fewer than in southern taxa.

A second factor which doubtless contributes to the potential for ecotypic variation is the degree of genetic isolation between eastern and western populations. Pan-Arctic species with good dispersal abilities might be the most homogeneous, followed by panArctic species with limited dispersive abilities and disjunct cold-temperate species. Disjunct warm-temperate and tropical species, which will have been separate since the initial cooling of the polar region, may be expected to be the most diverse. This hypothesis is based on the assumption that trans-oceanic dispersal is very rare and in some cases impossible (van den Hoek, 1987).

To test the above hypotheses, we have studied thermal response in a variety of amphi-Atlantic algae. We have found ecotypic variation with respect to high-temperature tolerance in one pan-Arctic species (Devaleraea ramentacea) whereas 2 other species (Chaetomorpha melagonium and Phycodrys rubens) were more homogeneous (Novaczek et al., 1990). In the latter species, differences occurred in growth rates and in resistance to sublethal temperatures but not in absolute tolerance limits. These results indicate that, within good morphological species, thermal tolerance is a genetically conservative feature and it may therefore reflect the geographical distribution of ancestral populations.

In the current study, we examined isolates of 2 species that are restricted to coldtemperate or marginally Arctic waters and therefore have little possibility for genetic exchange between disjunct, eastern and western Atlantic populations. One species Polyides rotundus (Huds.) Grev., or a close relative, is also recorded for the northern Pacific (Lindstrom, 1987). The second species, Furcellaria lumbricalis (Huds.) Lamouroux, is endemic to the Atlantic Ocean (Lindstrom, 1987).

\section{MATERIAL AND METHODS}

Furcellaria lumbricalis and Polyides rotundus were collected from sites in both Canada and Europe (Table 1). Clones were propagated from vegetative apices of the former, whereas juvenile tetrasporophytes were grown from carpospores of single plants of the latter species. All isolates were incubated in cool white fluorescent light in a range of temperature conditions to determine rates of growth and long-term survival capacity. Incubations were done in growth cabinets $\left( \pm 1-2{ }^{\circ} \mathrm{C}\right)$ at temperatures ranging from 5 to $30^{\circ} \mathrm{C}$, or in water baths $\left( \pm 0.5^{\circ} \mathrm{C}\right.$ ) at temperatures of 0 and $-2{ }^{\circ} \mathrm{C}$ (i.e. $-1.8^{\circ} \mathrm{C}$ in unfrozen seawater at $33 \%$ ). For all cultures, sterile PES medium (McLachlan, 1973), based on North Sea water of $33 \%$ salinity, was used. As $F$. lumbricalis may prefer a relatively low salinity (Bird et al., 1979), trials were also performed on this species using seawater diluted by the addition of fresh water to salinities of 20 and $27 \%$. 
Table 1. Place and year of collection of algal isolates; $(\mathfrak{t})=$ tetrasporophyte, $(\mathrm{u})=$ unknown

\begin{tabular}{|lll|}
\hline Species/Code & Location & Year \\
\hline Polyides rotundus & & \\
PCAN (t) & Pinkney Pt., N.S., Canada & 1986 \\
PHEL (t) & Helgoland, F.R.G. & 1987 \\
Furcellaria lumbricalis & & \\
FCAN1 (u) & Jarvin Island, Cape Breton, N.S., Canada & 1976 \\
FCAN2 (u) & Moosehead, N.S., Canada & 1979 \\
FDEN (u) & Nysted, Denmark & 1976 \\
\hline
\end{tabular}

Isolates were maintained in stock culture at $10^{\circ} \mathrm{C}$ in long days ( $16 \mathrm{~h}$ light, $8 \mathrm{~h}$ dark). In preparation for experiments, plants were moved from stock culture toward the desired experimental temperature at a rate of no more than $5^{\circ} \mathrm{C}$ wk ${ }^{-1}$ and then acclimated to the experimental temperature for at least 5 days. All material to be tested at a particular light and temperature condition received the same acclimation and all isolates were tested concurrently. Photon fluence rates of 10 and/or $40 \mu \mathrm{mol} \mathrm{m} \mathrm{m}^{-2} \mathrm{~s}^{-1}$ were used at each temperature. All trials were conducted in long days, except at $-2{ }^{\circ} \mathrm{C}$, where short $(8 \mathrm{~h}$ light, $16 \mathrm{~h}$ dark) days were employed.

For growth studies, 5 apices (Furcellaria lumbricalis) or juvenile plants (Polyides rotundus), all of approximately equal initial length, were used. Each apex or plant was placed in a $100-\mathrm{mm} \varnothing$, sterile plastic Petri dish 3/4 full of medium. Each dish was sealed with parafilm to prevent evaporation. The length of each apex was drawn at a standard magnification using a dissecting microscope fitted with a camera lucida. The culture dishes did not have to be opened, and the process was performed quickly to minimise temperature fluctuations. The drawings were later measured using a Hewlett Packard digitiser (model 9835A). Measurements were made at intervals of 2 to 10 days, depending upon the rate of growth, until a straight line on semi-log paper, indicating steady logarithmic increase, could be fitted through at least three consecutive data points. The relative growth rate (Kain, 1987), expressed as \% increase $\mathrm{d}^{-1}$, was computed for the period of exponential growth. Where no growth was apparent, measurements were discontinued after 4 weeks or when the material was obviously dead. Five replicates were averaged to give the mean growth rate for each isolate. Differences among isolates were tested by a posteriori SNK and Scheffe multiple range tests, using the Statistical Package for Social Sciences (SPSS).

To determine lethal limits, whole plants were incubated in 500-ml flasks at extreme temperatures for a period of 3 months. This relatively long incubation time was used in order to gain results relevant to survival over a summer or winter period in the field. Temperatures of $-2,0,25,27,30$ and $33^{\circ} \mathrm{C}$ were tested, in long and/or short daylengths. As high photon fluence rates appeared to hasten death at extreme temperatures, all tests were conducted at about $10 \mu \mathrm{mol} \mathrm{m}^{-2} \mathrm{~s}^{-1}$. Trials at $0{ }^{\circ} \mathrm{C}$ were also performed in darkness. The medium was changed at 2-3 week intervals, using media previously warmed or cooled to the appropriate temperatures to avoid thermal shock. After 3 months, the cultures were transferred to $10^{\circ} \mathrm{C}$, long days and observed for 1 month or until obvious growth had occurred. When test cultures appeared to be dead or dying in less than 
3 months, portions were removed to test for recovery. All tolerance tests were performed on at least 2 separate occasions. Short-term $(24 \mathrm{~h})$ tests were performed in darkness at $-5^{\circ} \mathrm{C}$ by freezing plants in seawater in test tubes in a water bath.

\section{RESULTS}

\section{Polyides rotundus}

The Canadian isolate (PCAN) tolerated freezing at $-5^{\circ} \mathrm{C}$, and both isolates survived 3 months at $-2{ }^{\circ} \mathrm{C}$ (short days) and $0^{\circ} \mathrm{C}$ (light or dark) (Table 2). There were no statistically significant differences between growth rates of the isolates at any tempera-

Table 2. Thermal tolerance of isolates of Polyides rotundus and Furcellaria lumbricalis in trials of 3 months duration, except " $=24 \mathrm{~h}$ duration. $\mathrm{L}=$ long days $(16 \mathrm{~h}), \mathrm{S}=\operatorname{short}$ days $(8 \mathrm{~h}), \mathrm{D}=$ dark $_{i}++=$ undamaged $+=$ damaged but recovered, $-=$ dead, nd $=$ no data

\begin{tabular}{|c|c|c|c|c|c|c|c|c|}
\hline \multirow[t]{2}{*}{ Species/isolate } & \multicolumn{8}{|c|}{ Temperature $\left({ }^{\circ} \mathrm{C}\right)$ and Daylength } \\
\hline & $-5 D^{*}$ & $-2 S$ & OD & $\mathrm{OL}$ & $25 \mathrm{~L}$ & $27 \mathrm{~L}$ & 30L & 33L \\
\hline \multicolumn{9}{|c|}{ Polyides rotundus } \\
\hline PCAN & ++ & ++ & ++ & ++ & ++ & + & - & - \\
\hline PHEL & nd & ++ & ++ & ++ & ++ & + & - & - \\
\hline \multicolumn{9}{|c|}{ Furcellaria lumbricalis } \\
\hline FCAN1 & ++ & ++ & ++ & ++ & $+t$ & - & - & \\
\hline FCAN2 & ++ & ++ & ++ & ++ & ++ & - & - & \\
\hline FDEN & ++ & ++ & ++ & ++ & ++ & - & - & \\
\hline
\end{tabular}

ture. Both isolates either did not grow or barely grew at -2 and $0{ }^{\circ} \mathrm{C}$, grew well from $5-25^{\circ} \mathrm{C}$, exhibited maximum growth at or above $10^{\circ} \mathrm{C}$, and had markedly depressed rates of growth above $25^{\circ} \mathrm{C}$ (Fig. 1). Whereas PCAN died within 2 weeks at $30^{\circ} \mathrm{C}$, the European isolate, PHEL, survived for at least 1 month. Neither isolate tolerated $33^{\circ} \mathrm{C}$ (Table 2).

\section{Furcellaria lumbricalis}

The Canadian (FCANl, FCAN2) and European (FDEN) isolates were homogeneous both in growth rates (Fig. 2) and in tolerance (Table 2) at all temperatures. Freezing was tolerated, as was darkness at $0^{\circ} \mathrm{C}$. Slow growth was recorded at $-2{ }^{\circ} \mathrm{C}$, moderate growth at 0 and $25^{\circ} \mathrm{C}$, and optimal growth occurred at $10-15^{\circ} \mathrm{C}$. Growth was markedly depressed at $20^{\circ} \mathrm{C}$, relative to that at $15^{\circ} \mathrm{C}$ (Fig. 2). All isolates died at $27^{\circ} \mathrm{C}$ (Table 2). Growth of all isolates was significantly reduced at salinities of 20 and $27 \%$, relative to that at $33 \%$ (Fig. 3).

\section{DISCUSSION}

In its ability to grow at $0{ }^{\circ} \mathrm{C}$ but not at temperatures exceeding $25^{\circ} \mathrm{C}$, Furcellaria lumbricalis resembled Arctic species. Polyides rotundus, with its limited capacity for growth at $0{ }^{\circ} \mathrm{C}$ and optimal growth up to $25^{\circ} \mathrm{C}$, has a more southerly affinity. This is reflected in both the northern and southern limits of geographic distribution of the 

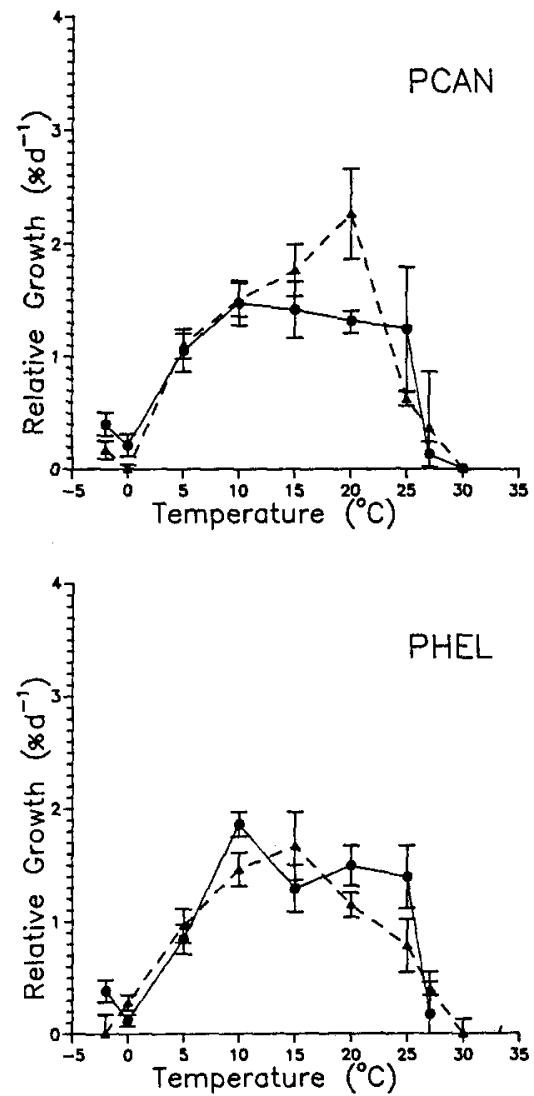

Fig. 1. Relative growth rates (mean \pm standard error) of isolates of Polyides rotundus at various temperatures and photon fluence rates of $10 \mu \mathrm{mol} \mathrm{m}{ }^{-2} \mathrm{~s}^{-1}$ (triangles) and $40 \mu \mathrm{mol} \mathrm{m}^{-2} \mathrm{~s}^{-1}$ (circles). Isolate indicated in upper right hand corner of each graph

species in the eastern Atlantic, where F. lumbricalis has a more northerly distribution (South \& Tittley, 1986).

F. lumbricalis occurs north to Spitzbergen (Kjellman, 1883), where temperatures range from -2 to about 3 or $5{ }^{\circ} \mathrm{C}$ (U.S. Navy, 1981), and may possibly occur in western Greenland (Kjellman, 1883, but no recent sightings). P. rotundus extends to the north coast of Norway (Rueness, 1977) and to western Novaya Zemlya (Kjellman, 1883) where the temperature ranges from -2 to about 4 or $6{ }^{\circ} \mathrm{C}$ (U.S. Navy, 1981). Judging from its thermal response in culture it would appear that the northern boundary of $P$. rotundus is determined by low summer temperatures that do not allow adequate growth. However, the northern limits of both species could also be imposed by a lack of adequate temperatures for reproduction.

In North America, both species have more limited northward extension than in Europe. Both are absent from the Canadian Arctic. Polyides rotundus occurs north to central Labrador (Wilce, 1959) whereas Furcellaria lumbricalis is found only in the Gulf of St. Lawrence and near the mouth of the Strait of Canso which leads from the Gulf to the 

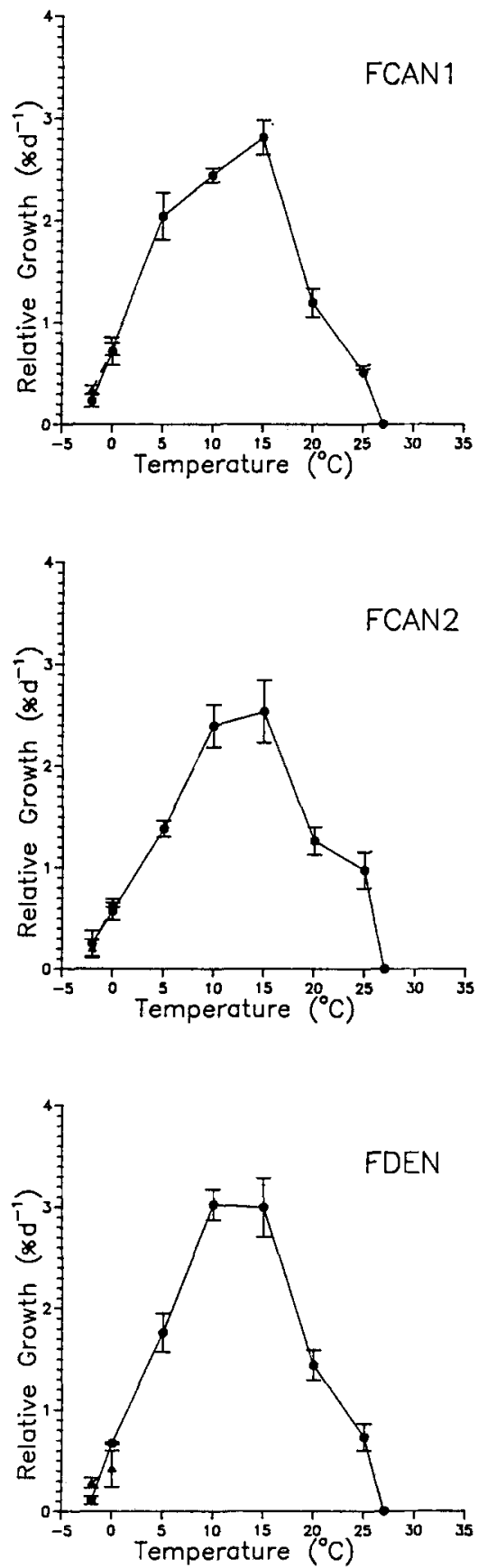

Fig. 2. Relative growth rates (mean \pm standard error) of isolates of Furcellaria lumbricalis at various temperatures and photon fluence rates of $10 \mu \mathrm{mol} \mathrm{m} \mathrm{m}^{-2} \mathrm{~s}^{-1}$ (triangles) and $40 \mu \mathrm{mol} \mathrm{m}^{-2} \mathrm{~s}^{-1}$ (circles). Isolate indicated in upper right hand corner of each graph 


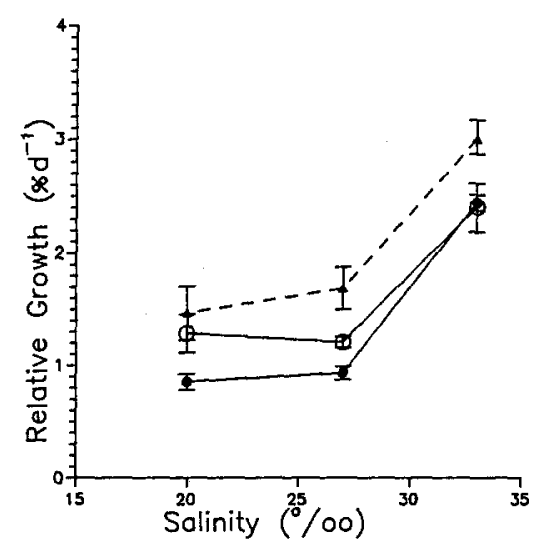

Fig. 3. Relative growth rates (mean \pm standard error) of isolates of Furcellaria lumbricalis at various salinities at $10^{\circ} \mathrm{C}$ in $16 \mathrm{~h}$ days and photon fluence rates of $40 \mu \mathrm{mol} \mathrm{m} \mathrm{m}^{-2} \mathrm{~s}^{-1}$. Isolate FCAN1 (closed circles); isolate FCAN2 (open circles); isolate FDEN (triangles)

Atlantic coast (Novaczek \& McLachlan, 1989). The hypothesis proposed by Bird et al. (1979) that the species is restricted to the Gulf of St. Lawrence owing to a preference for lower salinities is not borne out by our culture trials. Growth at reduced salinities was significantly depressed. The absence of $F$. lumbricalis from more southerly waters as well as from Labrador, where the temperature range of -2 to about $10^{\circ} \mathrm{C}$ (in sheltered inlets) should allow it to survive, adds weight to the theory (McLachlan, pers. comm.) that this species is a recent introduction to Canada and has not yet reached its potential limits of distribution on this coast.

In Europe, Polyides rotundus occurs as far south as the northwest shore of the Iberian Peninsula (Donze, 1968), near the $19^{\circ} \mathrm{C}$ August and $13^{\circ} \mathrm{C}$ February isotherms (U.S. Navy, 1981). There are unverified records from southeast Spain (Conde, 1984 after Bellon, 1921) and western Sicily (Furnari, 1984 but see Giaccone et al. 1985). In North America, the southern limit occurs just south of Cape Cod (Sears \& Wilce, 1975). Here, surface waters range from -2 to $21^{\circ} \mathrm{C}$, but the plant is typically found below $15 \mathrm{~m}$ depth, where summer temperatures are lower.

Neither the eastern nor the western Atlantic boundaries of Polyides rotundus can be explained by the upper or lower lethal limits of the species. Field records of reproduction are scattered and incomplete but it seems that in the northern sector of its range, $P$. rotundus is fertile in mid-summer (Kjellman, 1883) whereas in the North Sea fertile plants are found in autumn and winter (Kornmann \& Sahling, 1983). This suggests that $P$. rotundus has a very narrow temperature requirement for reproduction. The geographic distribution suggests that northern populations need summer temperatures to exceed $5{ }^{\circ} \mathrm{C}$ while southern populations need winter temperatures to drop below $15^{\circ} \mathrm{C}$.

In Europe, Furcellaria lumbricalis reaches south at least to Brittany in northern France, where temperatures range from a February average of $10^{\circ} \mathrm{C}$ to an August average of $16^{\circ} \mathrm{C}$ (U.S. Navy, 1981). There are unverified records from northwest Spain (Gallardo et al., 1985), southeast Spain (Conde, 1984, after Bellon, 1921) and Greece (Haritonidis \& Tsekos, 1975, 1976, but see Athanasiadis, 1987). As in the case of Polyides 
rotundus, the documented southern limit of $F$. lumbricalis in Brittany cannot be explained in terms of lethal limits. It may in part be due to the marked decrease in growth rate at temperatures above $15^{\circ} \mathrm{C}$. However, the species is abundant in the southern Gulf of St. Lawrence in Canada, where summer maxima commonly reach $20^{\circ} \mathrm{C}$. The southern limit may, therefore, indicate a requirement for low winter temperatures for reproduction. This species becomes fertile in winter throughout its distribution range (Rueness, 1977; Feldmann, 1954; South \& Hooper, 1980), and recent experimental evidence suggests that a combination of short days and low temperatures induces reproduction (McLachlan, pers. comm.).

To our knowledge, neither species has reproduced in culture, so that reproductive limits remain speculative. However, if European populations are limited in southern distribution by high winter temperatures that preclude reproduction, then Polyides rotundus and Furcellaria lumbricalis join a large group of amphi-Atlantic species for which this is the case (Breeman, 1988).

We hypothesized that, because of potentially easier genetic exchange, pan-Arctic species should be more homogeneous in thermal response than disjunct cold-temperate species. In Devaleraea ramentacea, 1 of 3 Arctic species tested, eastern and western Atlantic populations differed by about $2{ }^{\circ} \mathrm{C}$ in their upper tolerance limits and also differed in their growth potential at low temperatures (Novaczek et al., 1990). In contrast, and contrary to our hypothesis, eastern and western Atlantic populations of the coldtemperate species Polyides rotundus and Furcellaria lumbricalis were very homogeneous. This finding could reflect the fact that these species appear to be limited in geographic distribution by reproductive requirements rather than by tolerance limits. Hence, thermal tolerance is not under strong selective pressure, even in border populations. Variations in reproductive limits might therefore give a better indication of the degree of divergence of eastern and western populations.

Another possibility is that present distribution patterns are the result of (sub)recent dispersal events. Reconstructions of seawater temperatures during the last glaciation (CLIMAP Project Members, 1981) have shown that cold-temperate seaweed species, particularly those with narrow thermal ranges for reproduction, were faced with an extreme reduction of their distribution range, particularly in the western Atlantic (Breeman, 1990; van den Hoek \& Breeman, 1990). This is due to the very sharp latitudinal temperature gradient and the reduced seasonality on this coast during the ice ages (CLIMAP Project Members, 1981). In Europe, potential glacial distribution ranges remained much broader for species with these thermal characteristics. The absence of some cold temperature species (e.g. Laminaria hyperborea) from apparently hospitable American coasts has been attributed to glacial extinction without subsequent recolonization (van den Hoek \& Breeman, 1990). The very uniform thermal responses of eastern and western populations of Polyides rotundus and Furcellaria lumbricalis, and the fact that neither species extends over its full potential range on the American coast, suggest that these species may have succeeded in recolonizing this coast from the east after the last glaciation. Another amphi-Atlantic cold-temperate species with narrow temperature requirements, the green alga Cladophora sericea, is also very uniform, both in its thermal response (Cambridge et al., 1990) and in its genetic make-up (determined by means of DNA-DNA hybridization; Bot et al., 1989).

During the glacial, potential distribution ranges in the western Atlantic of Arctic 
algae such as Devaleraea ramentacea were less severely reduced than those of coldtemperate species because of their ability to grow and reproduce at very low temperatures. Thus western Atlantic populations may have persisted during the glacial, in which case they were isolated from eastern populations. If, on the other hand, western populations did become extinct, then postglacial recolonization could have occurred either from the North Pacific or from eastern Atlantic coasts. Both in the case of glacial persistence and of recolonization from the North Pacific, divergence times between current western and eastern populations would be longer than in the case of (sub)recent recolonization from the east as in cold-temperate species. This may account for the relative variability in thermal response found in some Arctic algae.

We have hypothesized that northern taxa in general should be more uniform than southern taxa which have occupied the Atlantic for a longer time and which have been more effectively disjunct between east and west. This hypothesis is supported by recent findings. In contrast to the uniformity or minor variability that we have found in cold temperate and Arctic taxa, are the relatively common and distinct ecotypic variants found among more southern taxa. For instance, among European isolates of the southern algae Stypocaulon scoparium (Novaczek et al., 1989) and Dasya baillouviana (Novaczek, unpubl.), variations were found in terms of growth and/or survival at both upper and lower thermal limits. In both of these cases there is evidence that some (Dasya) or all (Stypocaulon) North American populations are in fact sufficiently different from the European plants morphologically to be considered as separate species. Differences in lower lethal limits of as much as $5^{\circ} \mathrm{C}$ were also found between disjunct eastern and western Atlantic isolates of some tropical to warm temperate species such as Cladophora coelothrix (Cambridge et al., 1987) and several red algae (Breeman, unpubl.). Even larger differences in lower and/or upper lethal limits occur among isolates of cosmopolitan and polymorphic species complexes such as Ectocarpus siliculosus (Bolton, 1983) and Audouinella botryocarpa (Novaczek, unpubl.). The latter taxa are probably among the most ancient of those investigated. They could have entered the Atlantic over $100 \mathrm{my}$ ago from the Tethys Sea. Other cosmopolitan species are, however, more homogeneous in their thermal tolerance (e.g. Scytosiphon lomentaria; tom Dieck, 1987).

In conclusion, southern algal taxa generally differ from northern taxa of the North Atlantic Ocean in having more thermal ectoypes and greater degrees of ecotypic variation, in some cases coincident with speciation. This reflects a long residence time and a large degree of current and/or past disjunction among populations. Among northern taxa, there is so far no evidence linking ecotypic variation with degrees of current disjunction. Any such trend may be confounded by varied patterns of extinction and recolonization during glacial and post-glacial times.

Acknowledgements. The senior author was supported in this work by the Netherlands Organisation for the Advancement of Pure Research (ZWO). We wish to thank Drs A. F. Peters and J. McLachlan for providing us with culture material, Prof. Dr. C. van den Hoek for his support and Ms T. Linders for technical assistance.

\section{LITERATURE CITED}

Athanasiadis, A., 1987. A survey of the seaweeds of the Aegean Sea with taxonomic studies on species of the tribe Antithamniae (Rhodophyta). Ph. D. Thesis, Univ. of Gothenburg, $174 \mathrm{pp}$. 
Bellon, L., 1921. Contribución al estudio de la flora algológica del Mediterráneo español. - Boln Pescas 56-58, 81-119.

Bird, N. L., Chen, L. C.-M. \& McLachlan, J., 1979. Effects of temperature, light and salinity on growth in culture of Chondrus crispus, Furcellaria, lumbricalis, Gracilaria tikvahiae (Gigartinales, Rhodophyta), and Fucus serratus (Fucales, Phaeophyta). - Botanica mar. 22, 521-527.

Boiton, J. J., 1983. Ecoclinal variation in Ectocarpus silliculosus (Phaeophyceae) with respect to temperature growth optima and survival limits. - Mar. Biol, 73, 131-138.

Bot, P. V. M., Stam, W. T., Boele-Bos, S. A., Hoek, C. van den \& Delden, W. van, 1989. Biogeographic and phylogenetic studies in three North Atlantic species of Cladophora (Cladophorales, Chlorophyta) using DNA-DNA hybridization. - Phycologia 28, 159-168.

Breeman, A. M., 1988. Relative importance of temperature and other factors in determining geographic boundaries of seaweeds: experimental and phenological evidence. - Helgoländer Meeresunters. 42, 199-241.

Breeman, A. M., 1990. Expected effects of changing seawater temperatures on the geographic distribution of seaweed species. In: Expected effects of climatic change on marine coastal ecosystems. Ed. by J. J. Beukema, W. J. Wolff \& J. J. W. M. Brouns. Kluwer, Dordrecht, 69-76.

Cambridge, M. L., Breeman, A. M. \& Hoek, C. van den, 1990. Temperature responses limiting the geographical distribution of two temperate species of Cladophora (Cladophorales; Chlorophyta) in the North Atlantic Ocean. - Phycologia 29, 74-85.

Cambridge, M. L., Breeman, A. M., Kraak, S. \& Hoek, C. van den, 1987. Temperature responses of tropical to warm-temperate Cladophora species in relation to their distribution in the North Atlantic Ocean. - Helgoländer Meeresunters. 41, 329-354.

CLIMAP Project Members, 1981. Seasonal reconstructions of the earth's surface at the last glacial maximum. - The Geological Society of America Map and Chart Series, MC-36.

Conde, F., 1984. Catálogo de las algas macrobenthonicas marinas de Málaga. - Acta Bot. Malacit. 9, $47-78$.

Dieck, I. tom, 1987. Temperature tolerance and daylength effects in isolates of Scytosiphon lomentaria (Phaeophyceae) of the North Atlantic and Pacific ocean. - Helgoländer Meeresunters. 41, $307-321$.

Donze, M., 1968. The algal vegetation of the Ría de Arosa (NW Spain). - Blumea 16, 159-183.

Furnari, G., 1984. The benthic marine algae of southern Italy. - Webbia 38, 349-369.

Feldmann, J., 1954. Inventaire de la flore marine de Roscoff. - Trav. Stat. biol. Roscoff (Suppl.) 6, 1-152.

Gallardo, T., Gomez Garreta, A., Ribera, M. A., Alvarez, M. \& Conde, F., 1985. A preliminary checklist of Iberian benthic marine algae. Real Jardin Botanico, Madrid, 83 pp.

Gerard, V. A. \& Du Bois, K. R., 1988. Temperature ecotypes near the southern boundary of the kelp Laminaria saccharina. - Mar. Biol. 97, 575-580.

Giaccone, G., Colonna, P., Graziano, C., Mannino, A. M., Tornatore, E., Cormaci, M., Furnari, G. \& Scammacca, B., 1985. Revisione della flora marina di Sicilia e isole minori. - Boll. Accad. gioenia Sci. nat. $18,537-781$.

Haritonidis, S. \& Tsekos, I., 1975. Marine algae of northern Greece - Botanica mar. 18, $203-221$.

Haritonidis, S. \& Tsekos, I., 1976. Marine algae of the Greek west coast. - Botanica mar. 19, $273-286$.

Hoek, C. van den, 1987. The possible significance of long-range dispersal for the biogeography of seaweeds. - Helgoländer Meeresunters. 41, 261-272.

Hoek, C. van den \& Breeman, A. M., 1990. Seaweed biogeography of the North Atlantic Ocean: where are we now? In: Evolutionary biogeography of the marine algae of the North Atlantic. Ed. by G. R. South \& D. Garbary. Elsevier, Amsterdam (in press).

Kain, J. M., 1987. Seasonal growth and photoinhibition in Plocamium cartilagineum (Rhodophyta) off the Isle of Man. - Phycologia 26, 88-99.

Kjellman, F. R., 1883. The algae of the Arctic sea. Kongl. Boktryckeriet, Stockholm, 350 pp.

Kornmann, P. \& Sahling, P.-H., 1983. Meeresalgen von Helgoland. Biol. Anst. Helgoland, Hamburg, $289 \mathrm{pp}$.

Lindstrom, S., 1987. Possible sister groups and phylogenetic relationships among selected North Pacific and North Atlantic Rhodophyta. - Helgoländer Meeresunters. 41, 245-260.

McLachlan, J., 1973. Growth media - marine. In: Handbook of phycological methods: culture methods and growth measurements. Ed. by J. Stein. Cambridge Univ. Press, Cambridge, 25-51. 
Novaczek, I. \& McLachlan, J., 1989. Investigations of the marine algae of Nova Scotia XVII: Vertical and geographic distribution of marine macroalgae on rocky shores of the Maritime provinces. Proc. N.S. Inst. Sci. 38, 91-143.

Novaczek, I., Breeman, A. M. \& Hoek, C. van den. 1989. Thermal tolerance of Stypocaulon scoparium (Phaeophyta, Sphacelariales) from eastern and western shores of the North Atlantic Ocean. - Helgoländer Meeresunters. 43, 183-193.

Novaczek, I., Lubbers, G. W. \& Breeman, A. M., 1990. Thermal ecotypes of amphi-Atlantic algae. I. Algae of Arctic to cold-temperate distribution (Chaetomorpha melagonium, Devaleraea ramentacea, and Phycodrys rubens). - Helgoländer Meeresunters. 44, 459-474.

Rueness, J., 1977 . Norsk algeflora. Universitetsforlaget, Oslo, 266 pp.

Sears, J. R. \& Wilce, R. T.; 1975. Sublittoral, benthic marine algae of southern Cape Cod and adjacent islands: seasonal periodicity, associations, diversity, and floristic composition. - Ecol. Monogr. 45, $337-365$.

South, G. R. \& Hooper, R. G., 1980. A catalogue and atlas of the benthic marine algae of the island of Newfoundland. Mem. Univ. Newfoundl, - Occ, Pap. Biol. 3, 1-136.

South, G. R. \& Tittley, I., 1986. A checklist and distributional index of the benthic marine algae of the North Atlantic Ocean. British Museum (Natural History), London, $76 \mathrm{pp}$.

U.S. Navy, 1981. Marine climatic atlas of the world. Vol. 9: World-wide means and standard deviations. U.S. Government Printing Office, Washington.

Wilce, R. T., 1959. The marine algae of the Labrador peninsula and northwest Newfoundland (ecology and distribution). - Bull. natn. Mus. Can. 158, 1-103. 